Chadwick, B. \& Coe, K. 1983: Descriptive text to 1:100 000 sheet Buksefjorden 63 V.1 Nord, 70 pp. Copenhagen: Geol. Surv. Greenland.

Dymek, R. F., Weed, R. \& Gromet, L. P. 1983: The Malene metasedimentary rocks on Rype $\varnothing$, and their relationship to Amitsoq gneisses. Rapp. Grønlands geol. Unders. 112, 53-69.

Friend, C. R. L., Brown, M., Perkins, W. T. \& Burwell, A. D. M. 1985: The geology of the Qôrqut granite complex north of Qôrqut, Godthåbsfjord, southern West Greenland. Bull. Grønlands geol. Unders. 151, $43 \mathrm{pp}$.

McGregor, V. R. 1973: The early Precambrian gneisses of the Godthåb district, West Greenland. Phil. Trans. R. Soc. Lond. A 273, 343-358.

McGregor, V. R. \& Mason, B. 1977: Petrogenesis and geochemistry of metabasaltic and metasedimentary enclaves in the Amîtsoq gneisses, West Greenland. Amer. Miner. 62, 887-904.

Nutman, A. P. \& Bridgwater, D. 1983: Deposition of Malene supracrustal rocks on an Amîtsoq basement in outer Ameralik, southern West Greenland. Rapp. Grønlands geol. Unders. 112, 43-51.

\title{
Tungsten exploration in the southern part of the Godthåb area, West Greenland
}

\author{
Peter W. Uitterdijk Appel
}

Recent work by the Geological Survey of Greenland (GGU) in the Godthåb (Nûk) area has revealed a large tungsten province with extensive scheelite mineralisation in the Archaean Malene supracrustal rocks (Appel, 1983, 1984). In the area between Godthåb and Frederikshåb Isblink several large supracrustal amphibolite belts occur (fig. 1). These are presumably of the same age as the scheelite-bearing Malene amphibolites of the Godthåb area (Bridgwater et al., 1976). It was therefore decided to carry out a regional stream-sediment sampling programme in the area south of Godthåb, and this was accomplished in the summer of 1985. The aim of the programme was mainly to find scheelite, but the samples will subsequently be analysed for a number of other elements such as $\mathrm{Cu}, \mathrm{Pb}$ and $\mathrm{Mo}$.

The following report is mainly based on field observations. Laboratory work is confined to $\mathrm{X}$-ray determination of scheelite in three heavy mineral concentrates.

\section{General geology}

The geology of the area has been described by Bridgwater et al. (1976) and the reader is referred to that paper for a detailed account.

The most important rock-forming events in the area were the formation of the Amitsoq and Nûk gneisses. The Amîtsoq gneisses, which contain inclusions of Akilia supracrustal rocks, are the oldest, with isotopic ages of $3700 \mathrm{~m} . \mathrm{y}$. (Michard-Vitrac et al., 1977). The Nûk gneisses, which contain extensive outcrops of Malene supracrustals, are of the order of 3000 to 3200 m.y. old (Chadwick \& Coe, 1983). Contemporaneously with the Malene su- 


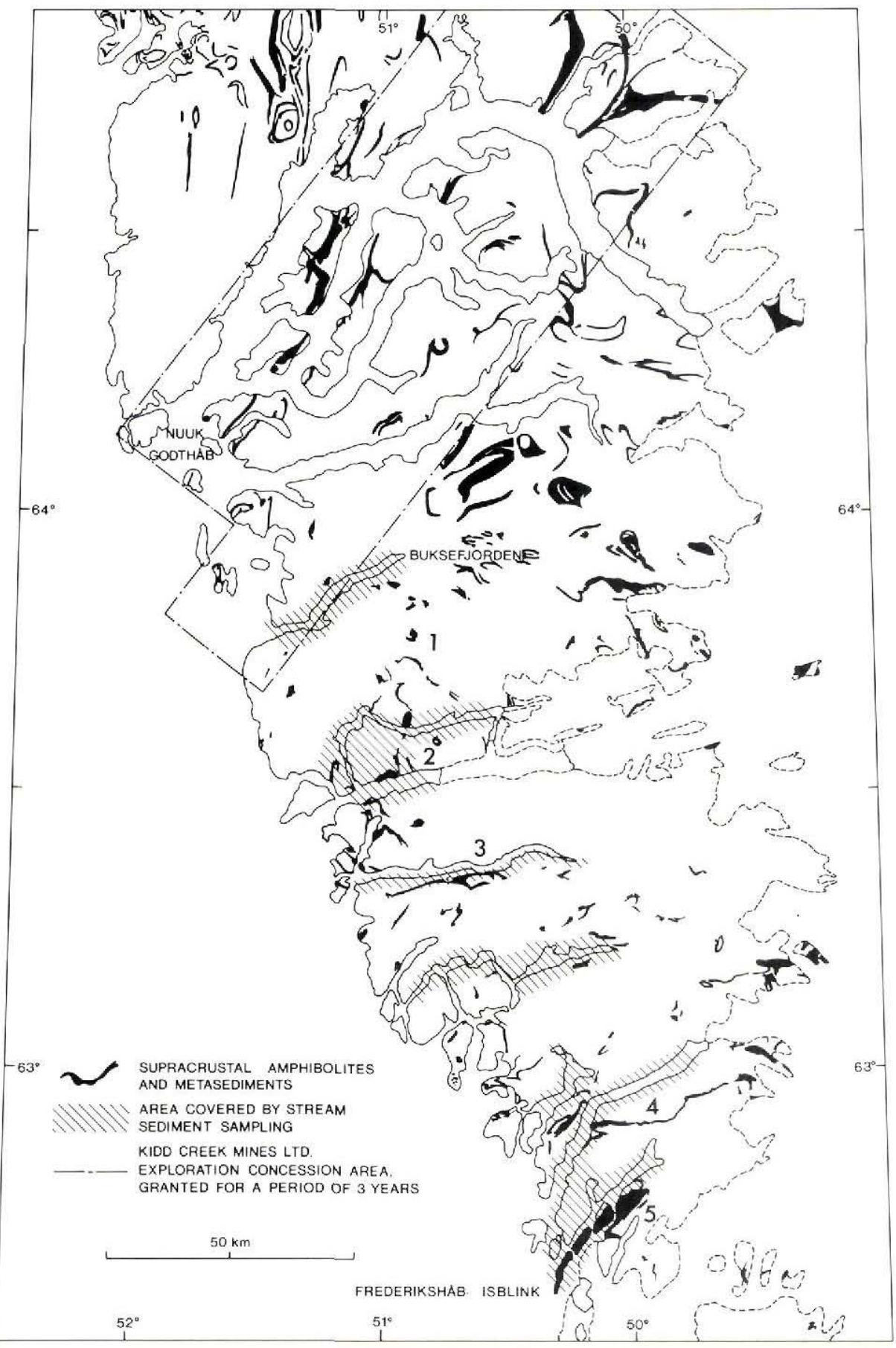

Fig. 1. Map showing major outcrops of Malene supracrustal rocks, and the area covered by the regional stream sediment sampling programme. 1: Taserssuatsiait. 2: Sermilik-Alángordlia. 3: Grædefjord. 4: Bjørnesund. 5: Íkátoq. 
pracrustals a major intrusive anorthosite complex was formed. The last major rock forming event was the formation of large intrusive granites during the Proterozoic. The area has been repeatedly deformed and has undergone several metamorphic events. Most of the area has been metamorphosed under amphibolite facies conditions but several large areas were metamorphosed under granulite facies conditions (Chadwick \& Coe, 1983).

The Malene supracrustal rocks and those south of Godthåb consist mainly of banded amphibolites, locally with pillow structures, and thin metasedimentary horizons. In several areas rust zones have been observed, a few metres in width and mostly containing pyrite, pyrrhotite and chalcopyrite. In the Malene supracrustals, stratabound scheelite-bearing tourmalinites associated with massive sulphides and an iron-formation are seen (Appel, 1985; Appel \& Garde, this report).

\section{Sampling programme}

Stream-sediment samples each weighing approximately $10 \mathrm{~kg}$ were collected from 134 streams in the areas shown on fig. 1. Each sample, consisting of a mixture of sand and gravel, was put through a $1 \mathrm{~mm}$ sieve and the coarse material was discarded. The finegrained material, usually amounting to 0.5 to 1 litre, was concentrated by panning. The heavy mineral concentrate was subsequently examined in ultra-violet light and the scheelite grains were counted. This procedure is the same as that used in previous surveys (Appel, 1983).

\section{Results}

Of the 134 streams sampled, 57 proved to contain scheelite. The scheelite content varied from a few grains up to 35 grains per sample. Many of the samples contained as many scheelite grains as the richest stream sediment samples from the Godthåb area.

The scheelite-bearing samples are not evenly distributed throughout the area; apart from a few exceptions, they are concentrated within a few areas listed below from north to south.

1. Taserssuatsiait. In this area two streams draining supracrustal amphibolites were sampled. The heavy mineral concentrates contained four and nine grains of scheelite; an amount which in West Greenland is considered highly anomalous (Appel, 1984).

2. Sermilik-Alángordlia. In the area between Sermilik and Alángordlia and on the north side of Alángordlia 31 streams were sampled; 21 contained scheelite, of which 13 contained more than five grains. All the scheelite-bearing streams drain supracrustal rocks in which abundant major rust zones occur. The Sermilik-Alángordlia area is particularly interesting, since part of the area has been metamorphosed under granulite-facies conditions, as a result of which primary syngenetic scheelite might have been mobilized and subsequently concentrated in smaller high-grade ore bodies.

3. Graedefiord. Along the south side of Gradefjord an extensive suite of supracrustal rocks occurs, and most of the streams draining these supracrustals contain scheelite.

4. Bjørnesund. In the Bjørnesund area a supracrustal sequence more than $50 \mathrm{~km}$ long occurs, which has shed rather high amounts of scheelite into the streams.

5. fkátoq. In this area a thick supracrustal sequence with well preserved pillow structures occurs. As a result of glacial erosion most of the area is flat with a poorly developed drainage pattern with only a few, small, slow running streams. In spite of this unfavourable drainage pattern several scheelite anomalies were discovered. 


\section{Conclusion}

This regional survey has shown that the West Greenland tungsten province is about 300 $\mathrm{km}$ long and up to $120 \mathrm{~km}$ wide. It is, however, likely that the tungsten province extends for at least another $100 \mathrm{~km}$ farther north. The survey has also outlined scheelite-bearing areas south of Godthåb, which seem to be just as promising from an economic point of view as the Kidd Creek Mines Ltd. exploration concession area.

Acknowledgements. The author is grateful to Charlotte Clausen for her valuable assistance in the field, and to $\mathrm{E}$. Leonardsen, Geological Institute, University of Copenhagen, for X-ray determination of the scheelite.

\section{References}

Appel, P. W. U. 1983: Tungsten in the Godthåb area, West Greenland. Rapp. Grønlands geol. Unders. $115,59-63$.

Appel, P. W. U. 1984: Tungsten mineralisation in the Godthåb area, West Greenland. Rapp. Grønlands geol. Unders. 120, 51-54.

Appel, P. W. U. 1985: Strata-bound tourmaline in the Archaean Malene supracrustals, West Greenland. Can. J. Earth Sci. 22, 1485-1491.

Bridgwater, D., Keto, L., McGregor, V. R. \& Myers, J. S. 1976: Archaean gneiss complex of Greenland. In Escher, A. \& Watt, W. S. (edit.) Geology of Greenland, 18-75. Copenhagen: Geol. Surv. Greenland.

Chadwick, B. \& Coe, K. 1983: Geological map of Greenland 1:100 000 Buksefjorden 63 V.1 Nord. Descriptive text. Copenhagen: Geol. Surv. Greenland.

Michard-Vitrac, A., Lancelot, J., Allegre, C. J. \& Moorbath, S. 1977: U-Pb ages on single zircons from the early Precambrian rocks of West Greenland and the Minnesota River Valley. Earth planet. Sci. Lett. 35, 449-453.

\section{Tungsten mineralisation in Archaean supracrustal rocks at Sermitsiaq, southern West Greenland}

\section{Hans Kristian Olsen}

The purpose of the field work was detailed mapping of the eastern part of the island Sermitsiaq in outer Godthåbsfjord, with special reference to its tungsten mineralisation (Appel, 1983). During six weeks in the summer of 1985 a geological map was made using enlarged aerial photographs at scale 1:10 000, and scheelite showings were localised with ultra-violet lamps at night (fig. 1). The following report is based on field observations and X-ray determination of scheelite in four rock samples. 